\title{
Analysis of the Influence of Leadership, Organizational Culture and Control Systems on Organizational Performance at Hasanuddin University Hospital
}

\author{
Yusi Irensi Seppa \\ Student of Magister Program of Management, STIE AMKOP, Makassar, Indonesia \\ yusiiren591987@gmail.com \\ Ansar, Muliaty Ansar \\ STIE AMKOP, Makassar, Indonesia \\ ansar.akkas@gmail.com, muliaty2675@gmail.com \\ Reski Dewi Pratiwi \\ STIKES Pelamonia Kesdam VII Wirabuana, Makassar, Indonesia \\ qkidewi@gmail.com \\ Yusriadi Yusriadi \\ Sekolah Tinggi Ilmu Administrasi Puangrimaggalatung, Makassar, Indonesia \\ yusriadi.yusriadi@uqconnect.edu.au \\ Muhammad Yusuf \\ Department of Public Administration, Halu Oleo University \\ yusuffia075@gmail.com \\ Andries Lionardo \\ University of Sriwijaya, Palembang, Indonesia \\ andrieslionardo@fisip.unsri.ac.id \\ Chairun Nasirin \\ College of Health Sciences (STIKES), Mataram, Indonesia \\ chairun.nasirin@stikes-mataram.ac.id
}

\begin{abstract}
This study aims to evaluate and examine the impact of leadership, organizational culture, and administrative performance management systems at Hasanuddin University Hospital Makassar. This research was conducted at Hasanuddin University Hospital Makassar from June to July 2020. The study method used is survey research using cross-section data, where information is obtained from respondents using a questionnaire whose population data is focused on the fact that all members of the population are sampled, namely 87 employees. The path analysis is used for statistical research. The findings indicate that leadership has a significant favourable influence on Hasanuddin University Hospital's organizational success in Makassar. The administration has a positive and considerable impact on the control system at Hasanuddin University Hospital in Makassar. Corporate culture has a positive but negligible effect on organizational success, and organizational culture has a positive and significant influence on the control system at Hasanuddin University Hospital in Makassar. The control system has a positive and substantial effect on the Hasanuddin University Hospital's organizational efficiency in Makassar. Leadership has a positive but no considerable impact on organizational success through the control system at Hasanuddin University Hospital in Makassar. Corporate culture has a positive but negligible influence on organizational success through the control system at Hasanuddin University Hospital in Makassar.
\end{abstract}

Keywords: Leadership, Organizational Culture, Control Systems and Organizational Performance 
Proceedings of the 11th Annual International Conference on Industrial Engineering and Operations Management Singapore, March 7-11, 2021

\section{Introduction}

An organization that achieves its objectives requires excellent and proper management. The organization's performance is determined by a variety of factors, including those who become participants in the entire operation of the organization, including human resources. Organizations are social organizations that are deliberately coordinated with identifiable boundaries and are often continuously working to achieve objectives. The organization's meaning can be seen in two ways: the first is that the organization is considered a forum for the managerial and administrative tasks to be carried out. The second is that it is viewed as a mechanism that emphasizes the relationship between the people involved in the organization.

Organizational performance is characterized as accomplishing administrative tasks by using resources effectively and efficiently to resolve various phenomena of organizational performance problems. Version is the performance of an individual against the company in which they operate and is a blend of skill and actions to achieve the best performance. Competent human resources carry out quality execution with dedication and discipline. How a company rewards and manages its human resources often impacts the attitudes and actions at the workplace.

Leadership is the aspect that affects organizational success. Leadership is a capacity to establish a specific goal, interact, and direct others to carry out the mission in question. It has been found that there has been a positive influence between leadership and organizational efficiency. Leadership impacts directly and has a positive effect on enhancing organizational efficiency. The power of supervision is a norm that individuals use and strive to influence others. This leadership is deemed acceptable when the aims conveyed by the organization can be embraced. Leaders must be able to apply the philosophy of leadership to the management of their subordinates where the leader can control the birth of the organization's objectives. Organizational culture has its problem phenomenon and therefore has an essential role in achieving its goal. Important is because the organizational culture is due to the behaviors or habituations that occur in the corporate hierarchy. It reflects the standards of actions carried out by its members. It indicates that this culture has a critical role for the business, where this culture is a method of disseminating the principles and values formed by the organization. In addition to organizational culture, the control structure is also a factor that influences organizational success. The control system is a structured targeting, tracking, assessment, and feedback system that provides managers with information about whether the plan and organizational structure are functioning efficiently and effectively. An effective 3-character control system is versatile enough to enable managers to respond to the unexpected, to provide accurate and timely information. The control system also has the role of ensuring that the tasks carried out are already in place and can be used to promote the progress of the control system stage, which is the chief's responsibility. The hospital, which is an entity offering health care to the city, often requires good management.

The government itself recognizes the value of maintaining a safe environment. It is crucial to support a developmental point where it would be difficult to achieve progress if the population becomes healthful. It is also the government's responsibility to provide adequate health care and benefits to society. The level of use of health facilities in the hospital is a significant predictor of the need to stress health services. One of the metrics used to explain the high and low use of existing beds in the hospital is the BOR (Bed Occupancy Rate). Low usage of BOR is in line with what it should be. The explanation for its content is that the poor quality of hospital care affects the low quality of service rendered. There is a decline in interest in other patients making hospital visits.

Based on research findings, it was found that the organizational efficiency of Hasanuddin University Hospital in Makassar was not satisfactory, one of which was indicated by the low percentage of BOR in that organization. As a consequence of this phenomenon, it is appropriate to increase and enhance organizational efficiency by paying attention to factors such as leadership, corporate culture, and control structures. Based on the above definition, the authors are asked to research the degree to which the characteristics of leadership, organizational culture, control structures influence the improvement of administrative efficiency. This research aims to know and analyze the impact of leadership, corporate culture, control system, on organizational performance at Hasanuddin University Hospital Makassar, according to the title and problem formulation.

\section{Literature Review}

The definition of leadership according to Robbins (2008) is the ability to influence a group to achieve a vision or set of specific goals. The source of this influence can be formal, such as that provided by the managerial positions in an organization (Bin Tahir \& Rinantanti, 2016). Because a management position has a formally recognized level of 
Proceedings of the 11th Annual International Conference on Industrial Engineering and Operations Management Singapore, March 7-11, 2021

authority, a person can assume a leadership role simply because of his position in the organization. Meanwhile, Hadari Nawawi and M. Martini Hadari (2004) say that leadership is a process or series of activities that are interconnected with one another, although they do not follow a systematic sequence.

The series contains activities to move, guide and direct and supervise other people in doing something, both individually and collectively. The leadership style has three basic patterns, which are further broken down into eight patterns. The three basic patterns of leadership style according to Hadari Nawawi and M. Martini (2004) are a pattern of leadership that emphasizes the implementation of tasks effectively and efficiently, in order to be able to achieve maximum goals. A patterned leadership style emphasizes the implementation of cooperative relationships and a patterned leadership style emphasizes the results that can be achieved in order to realize the goals of the group/organization. Leadership involves a deep relationship of influence, which occurs between people who want significant change, and these changes reflect the goals shared by the leader and his followers (subordinates) (Triantoro safara, 2004). Effective leadership will only be realized if it is carried out in accordance with its function. The leadership function is directly related to the social situation in the life of each group /organization, which implies that each leader is inside and not outside the situation. In order for the organizational culture to function optimally, the organizational culture must be created, maintained and strengthened and even changed by management, and introduced to employees through a socialization process so that employee values and organizational values can be united (A'yun et al., 2017). Through this socialization, employees are introduced to the goals, strategies, values and standards of organizational behavior, as well as information related to work (Nurtjahjani, 2007; Kanto et al., 2020; Umanailo, 2020; I Gede Juanamasta et al., 2019; Novitasari et al., 2019). Organizational culture at its most basic concept is the patterns of assumptions that are shared about how work is done in an organization.

According to Arifin (2005), in Purnomo B and Waridin, organizational culture must always be realized as best as possible. If there is a culture that is not good, there must be improvement with the support of all the organization's human resources. Including a firm leadership so as not only to improve employee performance, but also to support the achievement of organizational goals. Everything must be preceded by evaluating everything that is in the organization, especially regarding the organizational culture for the sake of achieving common organizational goals. For the improvement of organizational culture, everything that is not good in the organization, from the system to the organization's HR development process must be continuously improved. A strong work culture can create a conducive work atmosphere, so that the quality of work will be improved, which is the key to success for an organization or company. Owned work culture will be very valuable for the company and for employees.

\section{Research Method}

This analysis uses a quantitative approach since this research would show the effect between variables. The methodology used in data collection is based on a quantitative approach with an explanatory purpose, namely to clarify causal relationships and test hypotheses. This quantitative research approach is a research method based on the theory of positivism used in population or sample research, using data collection research tools, quantitative/statistical data analysis, the purpose of which is to evaluate the determination of the hypothesis (Sugiyono: 2014).

This study is a cross-section survey, where information is obtained from respondents using a questionnaire, the data from the population, and all population members are sampled. This research was conducted at the Makassar University Hospital in Hasanuddin. The sample $(S)=87$. The study used a saturated example since the total population of 87 people was sampled. The data analysis methodology used is the validation test, the reliability test, and the route analysis.

\section{Results}

\subsection{Data Analysis}

Based on the table below where all statements in the table are valid because the value of Pearson correlation / Corrected Item Total Correlation or R is calculated, which is greater than the R table (where $\mathrm{df}=85$ and $\alpha=5 \%$ ), which is greater than 0.2108 . hence the data can be used in this research in further analysis. 
Proceedings of the 11th Annual International Conference on Industrial Engineering and Operations Management Singapore, March 7-11, 2021

Table 1. Correlation

\begin{tabular}{|c|c|c|c|}
\hline Variable & Indicator Questions & $\begin{array}{c}\text { Corrected Item Total } \\
\text { Correlation }\end{array}$ & Conclusion \\
\hline \multirow{5}{*}{ Leadership (X1) } & $\mathrm{X} 1.1 .1$ & 0.672 & Valid \\
\hline & $\mathrm{X} 1.1 .2$ & 0.808 & Valid \\
\hline & $\mathrm{X} 1.1 .3$ & 0.828 & Valid \\
\hline & $\mathrm{X} 1.1 .4$ & 0.780 & Valid \\
\hline & $\mathrm{X} 1.1 .5$ & 0.751 & Valid \\
\hline \multirow{5}{*}{$\begin{array}{c}\text { Culture } \\
\text { Organization (X2) }\end{array}$} & $\mathrm{X} 2.2 .1$ & 0.741 & Valid \\
\hline & $\mathrm{X} 2.2 .2$ & 0.772 & Valid \\
\hline & $\mathrm{X} 2.2 .3$ & 0.630 & Valid \\
\hline & $\mathrm{X} 2.2 .4$ & 0.716 & Valid \\
\hline & $\mathrm{X} 2.2 .5$ & 0.577 & Valid \\
\hline \multirow{5}{*}{ Control System (Y1) } & Y1.1.1 & 0.734 & Valid \\
\hline & $\mathrm{Y} 1.1 .2$ & 0.604 & Valid \\
\hline & Y1.1.3 & 0.786 & Valid \\
\hline & Y1.1.4 & 0.827 & Valid \\
\hline & Y1.1.5 & 0.770 & Valid \\
\hline \multirow{10}{*}{$\begin{array}{c}\text { Organizational } \\
\text { Performance (Y2) }\end{array}$} & Y2.2.1 & 0.535 & Valid \\
\hline & Y2.2.2 & 0.726 & Valid \\
\hline & Y2.2.3 & 0.690 & Valid \\
\hline & Y2.2.4 & 0.745 & Valid \\
\hline & Y2.2.5 & 0.777 & Valid \\
\hline & Y2.2.6 & 0.681 & Valid \\
\hline & Y2.2.7 & 0.696 & Valid \\
\hline & Y2.2.8 & 0.270 & Valid \\
\hline & Y2.2.9 & 0.563 & Valid \\
\hline & Y2.2.10 & 0.767 & Valid \\
\hline
\end{tabular}

Source: Primary data processed, 2020

For the reliability test, through the Cronbach Alpha method, a measured coefficient value for reliability can be obtained above 0.6 and above the threshold. It can be concluded that the overall variable has reliability or (reliable) or consistency.

Table 2. Coefficients

\begin{tabular}{|c|c|c|c|}
\hline Variable & Cronbach's Alpha & N of Item & Conclusion \\
\hline Leadership (X1) & 0.825 & 5 & Reliable \\
\hline Organizational Culture (X2) & 0.718 & 5 & Reliable \\
\hline Control System (Y1) & 0.800 & 5 & Reliable \\
\hline $\begin{array}{c}\text { Organizational } \\
\text { Performance (Y2) }\end{array}$ & 0.839 & 10 & Reliable \\
\hline
\end{tabular}

Source: Primary data processed, 2020

For Path analysis, Leadership Variable Regression Coefficient (X1) and Organizational Culture (X2) on Control System (Y1).

Table 3. Coefficients ${ }^{a}$

\begin{tabular}{|c|c|c|c|c|c|c|}
\hline & & Unstandardiz & Coefficients & $\begin{array}{l}\text { Standardized } \\
\text { Coefficients }\end{array}$ & & \\
\hline & & $\mathrm{B}$ & Std. Error & Beta & $\mathrm{t}$ & Sig. \\
\hline 1 & (Constant) & 6,152 & 1,865 & & 3,299 & .001 \\
\hline & Leadership & .254 & .105 & .275 & 2,403 & .018 \\
\hline & Organizational & .428 & .119 & .411 & 3,595 & .001 \\
\hline
\end{tabular}


Proceedings of the 11th Annual International Conference on Industrial Engineering and Operations Management Singapore, March 7-11, 2021

\begin{tabular}{|l|l|l|l|l|l|}
\hline & culture & & & & \\
\hline
\end{tabular}

Dependent Variable: Control System

Based on the table above, the significance level values of each of the leadership and organizational culture variables are 0.018 and 0.001 , which are smaller than 0.05 . Then the $t$ value obtained for each variable of leadership and organizational culture is 2.403 and 3.595 , where both values are greater than the $\mathrm{t}$ table value (for $\mathrm{df}=85$ and $\alpha=$ $5 \%$ ). The path coefficient (Beta) of each leadership and organizational culture variable on the control system is 0.275 and 0.411 . Furthermore, in the table, it can be seen that the coefficient of determination (R Square) is 0.396 . The coefficient of determination shows the contribution of leadership and organizational culture on the control system by $39.6 \%$. The determination of the value of e1 is obtained by the formula: $\mathrm{e} 1=\sqrt{ }(1-\mathrm{R}$ Square $)$, so that the value of e1 $=\sqrt{ }(1-0.396)=0.604$ is obtained.

Leadership Variable Regression Coefficient (X1), Organizational Culture (X2), and Control System (Y1) on Organizational Performance (Y2)

Table 4. Coefficients ${ }^{\text {a }}$

\begin{tabular}{|c|c|c|c|c|c|c|}
\hline \multirow{2}{*}{\multicolumn{2}{|c|}{ Model }} & \multicolumn{2}{|c|}{ Unstandardized Coefficients } & \multirow{2}{*}{$\begin{array}{c}\text { Standardized } \\
\text { Coefficients } \\
\text { Beta } \\
\end{array}$} & \multirow[b]{2}{*}{$\mathrm{t}$} & \multirow[b]{2}{*}{ Sig. } \\
\hline & & B & Std. Error & & & \\
\hline \multirow[t]{4}{*}{1} & (Constant) & 7,801 & 3,451 & & 2,260 & .026 \\
\hline & Leadership & .526 & .190 & .295 & 2,772 & .007 \\
\hline & $\begin{array}{l}\text { Organizational } \\
\text { culture }\end{array}$ & 071 & .222 & .035 & .320 & .749 \\
\hline & Control System & .937 & .190 & .485 & 4,932 & .000 \\
\hline
\end{tabular}

Dependent Variable: Organizational Performance

Based on the table above, the significance level of each variable of leadership, organizational culture, and control system is $0.007,0.749$, and 0.0001 . The significance of the leadership and social system variables is less than 0.05 , while the organizational culture variable's significance is greater than 0.05 . The $t$ value obtained for each of the leadership variables and organizational culture is $2.772,0.320$, and 4,932. The $t$ value for the leadership variable and the social system was greater than the $\mathrm{t}$ table value (for $\mathrm{df}=85$ and $\alpha=5 \%$ ), namely 1.988 . In comparison, the $\mathrm{t}$ value for the organizational culture variable was smaller than the $t$ table value. This means that the leadership and control system variables have a significant direct effect on organizational performance, while the direct influence of organizational culture is not significant on organizational performance. The path coefficient (Beta) of each variable of leadership, organizational culture, and control system on organizational performance is 0.295., 0.035, and 0.485. Furthermore, in table 4, the coefficient of determination (R Square) is 0.515 . The value of $\mathrm{e} 2=\sqrt{ }(1-0.515)=0.485$.

Referring to the diagram above, determining the indirect effect (through control system variables) between leadership variables on organizational performance and between corporate culture on organizational performance is as follows:

1. The indirect effect leadership (X1) control system (Y1) on organizational performance (Y2) (product of the coefficient X1 to Y1 with the coefficient of Y1 to Y2) $=0.275 \times 0.485=0.133$

2. Indirect influence of organizational culture (X2) through the control system (Y1) on organizational performance (Y2) (product of the coefficient X2 to Y1 with the coefficient of Y1 to Y2) $=0.411 \times 0.485=$ 0.199 .

Table 5. Indirect Effect

\begin{tabular}{|c|c|c|c|}
\hline Effects of Change & Live & Indirect (Through Y1) & Total \\
\hline X1 against Y2 & 0.295 & 0.133 & 0.428 \\
\hline X2 against Y2 & 0.035 & 0.199 & 0.234 \\
\hline Y1 against Y2 & 0.485 & - & 0.485 \\
\hline X1 against Y1 & 0.275 & - & 0.275 \\
\hline
\end{tabular}


Proceedings of the 11th Annual International Conference on Industrial Engineering and Operations Management Singapore, March 7-11, 2021

\begin{tabular}{|l|l|l|l|}
\hline X2 against Y1 & 0.411 & - & 0.411 \\
\hline
\end{tabular}

Source: Results of SPSS data processing, 2020

\section{Discussion}

\subsection{The Effect of Leadership on Organizational Performance}

The research results of testing the first hypothesis show that leadership positively and significantly affects organizational performance; this is indicated by the value of $t$-count $2.772>t$-table 1.988 with a significance value of 0.007. The influence of the leadership variable (X1) on organizational performance has a path coefficient value which shows a positive sign of 0.295 . This indicates that the more consistent and effective leadership is, the organizational performance at Hasanuddin University Hospital in Makassar will increase, and vice versa if the administration is more inconsistent and practical, the organizational performance will also below.

\subsection{The Effect of Leadership on the Control System}

The research results of testing the second hypothesis indicate that leadership positively and significantly affects the control system. This is indicated by the value of t-count $2.403>t$-table 1.988 with a significance value of 0.018 . The influence of the leadership variable (X1) on the control system has a path coefficient value that shows a positive sign of 0.275 . This indicates that the more consistent and effective the leadership is, the more influential the control system at Hasanuddin University Hospital will be, and vice versa if the administration is more inconsistent and practical, the control system will also below.

\subsection{The Influence of Organizational Culture on Organizational Performance}

The study results regarding the value of t-count $0.320<\mathrm{t}$-table 1.988 with a significant deal of 0.749 indicate that organizational culture has a positive but not significant effect on organizational performance. The influence of the managerial culture variable (X2) on organizational performance has a path coefficient value which shows a positive sign of 0.035 . This indicates that the higher the organizational culture, the higher the organizational performance at Hasanuddin University Hospital Makassar, and vice versa if the corporate culture is low. Then organizational performance will also below.

\subsection{The Influence of Organizational Culture on Control Systems}

The research results on testing the fourth hypothesis indicate that organizational culture has a positive and significant effect on the control system; this is indicated by the value of t-count 3.595> t-table 1.988 with a significance value of 0.001 . The influence of the organizational culture variable (X2) on the control system has a path coefficient value that shows a positive sign of 0.411. This indicates that the higher the corporate culture, the control system at Hasanuddin University Hospital in Makassar will increase, and vice versa, if the lower the organizational culture, the control system will also below.

\subsection{Effect of Control Systems on Organizational Performance}

The fifth hypothesis research results indicate that the control system has a positive and significant effect on organizational performance. This is indicated by the value of t-count 4,932>t-table 1,988 with a significance value of 0,000 . The control system variable (Y1) on organizational performance has a path coefficient value that shows a positive sign of 0.485 . This indicates that the higher / better the organizational control system, the organizational performance at Hasanuddin University Hospital in Makassar will also increase, and vice versa if the control system is low, the organizational performance is too low or not optimal.

\subsection{The Influence of Leadership on Organizational Performance through Control Systems}

The study results with a direct effect value of 0.295 , while the indirect effect of 0.133 means that the immediate effect's value is greater than the value of the indirect effect. This shows that the influence of leadership on organizational performance through the control system is positive but not significant. If the administration is consistent and effective, the control system will also be practical and increase. The organizational performance at Hasanuddin University Hospital in Makassar will also increase. 
Proceedings of the 11th Annual International Conference on Industrial Engineering and Operations Management Singapore, March 7-11, 2021

\subsection{The Influence of Organizational Culture on Organizational Performance through Control Systems}

The research results for testing the seventh hypothesis indicate that organizational culture has a positive but insignificant effect on organizational performance through the control system. This is indicated by the direct effect value of 0.035 , while the indirect effect is 0.199 . This shows that organizational culture's influence on corporate performance through the control system is a positive but insignificant effect. Based on this, if the organizational culture is high or practical, the control system will also increase. The corporate performance at the Hasauddin University Hospital in Makassar will also increase.

\section{Conclusion}

Based on the results of research and discussion in the previous chapter regarding the Influence of Leadership, Organizational Culture, and Control Systems on Organizational Performance, it can be concluded that the Influence of Leadership Variables (X1), Organizational Culture (X2), and Control Systems (Y1) on Organizational Performance (Y2) has a positive and significant effect on organizational performance. This can be seen in the ANOVA table showing that the calculated $f$ value for the influence of leadership, organizational culture, and control systems on the organizational performance obtained is 29.416 . When compared with the value of $\mathrm{ftable}$ (for df $1=3$, $\mathrm{df} 2=84$ ) which is 2.71 , the calculated $\mathrm{f}$ value is greater than $\mathrm{f}$ table, while significant $\alpha=0.000$. This concludes that leadership, organizational culture, and control systems simultaneously significantly affect organizational performance.

\section{References}

Abd Rahman, Akmal Umar, \&Nur Fattah.(2018). Pengaruh Gaya Kepemimpinan dan Pengawasan terhadap efektivitas kerja melalui Disiplin Kerja Pegawai di Kecamatan Ulaweng Kabupaten Bone.

Abdurrahman dan Muhidin.(2007). Analisis Korelasi, Regresi dan Jalur Penelitian. Bandung: CV Pustaka Setia.

A'yun, K., Suyono, Poedjiastoeti, S., \& Bin-Tahir, S. Z. (2017, August). Reduction of cognitive conflict and learning style impact towards student-teacher's misconception load. In AIP Conference Proceedings (Vol. 1868, No. 1, p. 030004). AIP Publishing LLC.

Baldauf, Artur, David W Cravens dan Nigel Piercy. (2001). Examining Business Strategy, Sales Management, and Salesperson Antecedent of Sales OrganisationEffectiveness,Journal of Personal Selling \& Sales Management, Vol XXI. No.2.

Basri A.R., Muhammad. (2013). Budaya Organisasi dan Pelayanan Publik Suatu Pendekatan dalam Pelayanan.Makassar: Yapma.

Bin-Tahir, S. Z., \& Rinantanti, Y. (2016). Multilingual lecturers' competence in English teaching at the university of Iqra Buru, Indonesia. Asian EFL Journal, 5, 79-92.

Chang, Tung Zong dan Su Jane Chen, (1998). Market Orientation, Service Quality and Business Profitability : a Conceptual Model ad Empirical Evidence, Journal of Service Marketing, Vol. 21.

Dharma, S \&Akib, H. (2004).Budaya Organisasi Kreatif: Mencermati Budaya Organisasi sebagai Faktor Determinan Kreativitas, Jurnal Manajemen USAHAWAN. Nomor 03/TH.XXXIII Maret 2004.

Djojosugito, Ahmad. (2001).Kebijakan Pemerintah dalam Bidang Pelayanan Kesehatan Menyongsong AFTA (2003), www.Pdpersi.co.id.

Edgar H. Schein. (2006). Organizational culture and leadership, Jossey-Bass A Wiley Imprint, San Francisco.

Firman.(2019). Pengaruh Pengawasan Dan Komitmen Organisasi Terhadap Kinerja Melalui Disiplin Kerja di Dinas Pendidikan dan Kebudayaan Kabupaten Soppeng. Sekolah Tinggi Ilmu Ekonomi Amkop, Makassar.

Goleman, Daniel, Richard Boyatzis, dan Annie McKee. (2003). Primal leadership.Realizing the Power of Emotional Intelligence.Massachusetts: Harvard Business School Press.

Hasibuan, Malayu, S.P. (2006). Manajemen Sumber Daya Manusia(Edisi Revisi), Jakarta: Bumi Aksara.

Hasibuan,\&Malayu S.P (2013). Manajemen Sumber Daya Manusia.Jakarta PT. Bumi Aksara.

Indrianto, Nur, BambangSupomo, (2009). Metodologi Penelitian Bisnis untuk Akuntansi dan Manajemen, Edisi Pertama.Yogyakarta : BPFE Yogyakarta.

Juanamasta, I.G., Wati, N. M. N., Hendrawati, E., Wahyuni, W., Pramudianti, M., Wisnujati, N. S., Setiawati, A. P., Susetyorini, S., Elan, U., Rusdiyanto, R., Astanto, D., Ulum, B., Khadijah, S. N., Trimarjono, A., Syafii, M., Mubarroq, A., Kristiningsih, K., Pratiwi, R. D., Veri, V., ... Umanailo, M. C. B. (2019). The role of customer service through customer relationship management $(\mathrm{Crm})$ to increase customer loyalty and good image. International Journal of Scientific and Technology Research, 8(10). 
Proceedings of the 11th Annual International Conference on Industrial Engineering and Operations Management Singapore, March 7-11, 2021

Kanto, S., Wisadirana, D., Chawa, A. F., \& Umanailo, M. C. B. (2020). Change in community work patterns. Proceedings of the International Conference on Industrial Engineering and Operations Management, 0 (March), 2496-2502

Kuntjoro.(2002). Komitmen Organisasi.Artikel.

Luthans, Fred. (2006). Organization Behavior (Prilaku Organisasi), Yogyakarta.

Luthans, F (2014). Organization Behavior. New York : McGraw Hill International.

Mangkunegara (2009).Evaluasi Kinerja Sumber Daya Manusia. Bandung: Penerbit RefikaAditama.

Mangkunegara, A.A., \& Anwar P, (2012).Manajemen Sumber Daya Manusia.Bandung : PT. Remaja Rosdakarya.

Marwangsyah.(2016). Manajemen Sumber Daya Manusia. Edisi Dua. Cetakan keempat.Bandung :Alfabeta, CV.

Muliaty.(2018).Pengaruh transformasi dan budaya organisasi terhadap kinerja pegawai Badan Perizinan Terpadu dan Penanaman Modal (BPTPM) Kota Makassar.Universitas Negeri Makassar, Makassar.

Novitasari, R., Usanti, T. P., Adiansha, A. A., Soesantari, T., Said, M. F., Hanapi, H., Indrayani, N., Kubangun, H., Nur, M., Musa, D., Ar, N., Qomaria, R., Marasabessy, R. N., Tuaputy, U. S., Widyawati, N., Prastyorini, J., Wali, M., P, N. D., Soedarmanto, S., \& Umanailo, M. C. B. (2019). The Existence of Waranggana in Tayub Ritual. International Journal Of Scientific \& Technology Research Volume, 8(10). http://www.ijstr.org/research-paper-publishing.php?month=oct2019

Reza Zarvedi, Rusli Yusuf dan Mahdani Ibrahim. (2016), Pengaruh Kepemimpinan, Budaya Organisasi dan Kompetensi Terhadap Kinerja Pegawai Serta Implikasinya pada Kinerja Sekretariat Kabupaten Pidie Jaya, Jurnal Perspektif Ekonomi Darussalam, Vol.

Rivai, V. (2014).Manajemen Sumber Daya Manusia Untuk Perusahaan. Jakarta: Murai Kencana.

Robbins \& Judge. (2013). Organizational Behavior, Fifteenth Edition. Pearson Education, Inc.

Siagian, P. Sondang. (2003). Teori dan Praktek Kepemimpinan.Rineka Cipta, Jakarta.

Umanailo, M. C. B. (2020). Development of science and technology towards the formation of participatory spaces. Proceedings of the International Conference on Industrial Engineering and Operations Management.

\section{Bibliography}

Yusi Irensi Seppa is a student at Magister Program of Management of STIE AMKOP, Indonesia. His areas of interest and research include social science and economic. She has published some articles in national journals

Ansar is a lecturer at Economics Department of STIE AMKOP, Indonesia. His areas of interest and research include economic, management, management human resource. He has published some books and many articles in national and international journals. He is a reviewer and editor in some local and international journals.

Muliaty Ansar is a lecture at Economics Department of STIE AMKOP, Indonesia. Her areas of interest and research include social science, economic and management. She has published some articles in national and international journals.

Reski Dewi Pratiwi is a lecturer at Hospital Administration Department of STIKES Pelamonia Kesdam VII Wirabuana, Indonesia. Her areas of interest and research include hospital administration, public health, and education. She has published some articles in national journals.

Yusriadi Yusriadi is a lecturer at Public Administration Department of Sekolah Tinggi Ilmu Administrasi Puangrimaggalatung, Indonesia and chancellor on Sekolah Tinggi Ilmu Hukum Pengayoman. His areas of interest and research include social science, political science, sociology, legal studies, and public administration. He has published some books and many articles in national and international journals. He is a reviewer and editor in some local and international journals.

Muhammad Yusuf, is an Assistant Professor Department of Public Administration, Faculty of Social and Political Sciences, Halu Oleo University. He graduated from Halu Oleo University Kendari, graduated his master from Hasanuddin University, and doctoral degree from Hasanuddin University in the field of public administration. Her areas of interest and research include all issue about state administration, public administration, and business administration. She also has published some articles in national and international journals. 
Proceedings of the 11th Annual International Conference on Industrial Engineering and Operations Management Singapore, March 7-11, 2021

Andries Lionardo is a lecturer and researcher at the faculty of social and political studies, University of Sriwijaya, Palembang, Indonesia. Some of his research is related to public administration and public policy. His research interests include Good government, public service quality, local government accountability, and public budgeting.

Chairun Nasirin is a lecturer at College of Health Sciences (STIKES Mataram), Indonesia. His research is related to health administration and health policy. Some of his research interests include health administration, community nursing, empowerment, health policy, and public health. 